\title{
Technical development to assess soil health using soil health index in Indonesia
}

\author{
Latief Mahir Rachman * \\ Department of Soil Science and Land Resources, Bogor Agricultural University, Bogor, Indonesia
}

\section{Keywords \\ Environmental \\ Sustainability \\ Soil health \\ Assessment}

Received: 7 August 2018

Accepted: 3 November 2018

Published: 1 October 2018

\begin{abstract}
The technique developed to assess or measure soil health in Indonesia proposed by the author is to use soil health index by using a minimum data set consisting of 13 (thirteen) main parameters of soil equipped with the function or role of each parameter along with its weighting coefficient and how to assess each parameter and calculate the total health score of the soil studied. Furthermore, the total health score of the soil then classified into 5 levels of soil health, varying from very well to very poor levels. To select indicators used for assessment or measurement of soil health in Indonesia, the author uses some criteria proposed by some authors formerly. The author selects a technique proposed to develop SHI. The technique is "score-based" and operates in two synergistic steps. The findings show that soil health basically reflects the character and dynamics of the soil in fulfilling its functions. However, a variation on the function of soil causes difficulties in compiling a soil health assessment that can measure to which extent the soil can fulfill all of its dedicated functions. Ironically, in Indonesia, there are no tools that have been developed and used extensively, and standardized to assess soil health. Thus the development of tools to assess soil health is an urgent need in Indonesia.
\end{abstract}

(C) 2018 The Author(s). Published by TAF Publishing.

\section{INTRODUCTION}

Soil health is an essential factor for maintaining productivity and quality of agriculture products namely food, fiber, and wood as well as supporting human health and environmental quality. Towards the era of disruption, agriculture 4.0 , industry 4.0 and sustainable development, accurate and practical data on natural resources, including soil health, is important. Soil health data is needed for various purposes such as for having an optimal utilization plan and rehabilitation of degraded lands and soils; assessing the accordance of the applied land and soil management with the necessities and requirements; and assessing the health of the soil as an impact of the land or soil management systems used. The use of soil health data is not only related to agriculturerelated activities, e.g., food production and clothing and shelter, but also to other fields that use soil for maintaining water and air quality, support human health and preserving the environment [1]. As an example, food products released from soil contaminated with heavy metals from mining and industry or residues from pesticides, herbicides, fungicides (mainly from $\mathrm{Cd}, \mathrm{Cu}, \mathrm{Ni}, \mathrm{Pb}, \mathrm{Zn}, \mathrm{Hg}, \mathrm{Cr}$ ) and other toxic components are harmful to human health. In a broader perspective, soil health is critical in supporting food security, water security, climate change mitigation and biodiversity protection programs $[2,3]$. Thus, maintaining and sustaining soil health should receive greater attention in order to increase agricultural productivity as well as to improve environmental quality for gaining better support for human life.

The term soil health is similar or often exchanges each other with soil quality. Even though in the context of ecosystems, soil health is not the same as soil quality. In the aspect of the time scale, in some cases, soil health can better describe the potential and dynamic conditions of the soil in a short time, while soil quality better describes the condition of inner and static soils on a longer time scale [4]. While the term soil quality will generally be associated with land suitability for certain uses [5], soil health is used in a broader

\footnotetext{
*Corresponding author: Latief Mahir Rachman

†email: latiefra@apps.ipb.ac.id
} 
sense to show the capacity of the soil to function as a vital living system $[6,7]$. Soil health focuses more on the biotic components of the soil, reflecting the maintenance of soil organisms and their proper functions to regulate nutrient cycles and soil fertility [8]. Food and Agriculture Organization (FAO) describes soil health as the capacity of the soil to function as a living system with ecosystem boundaries and land use to maintain or improve water and air quality and the health of plants and animals [9]. Healthy soils maintain a community of diverse soil organisms that help control diseases of plants, insects and pests weeds, forming beneficial symbiotic associations with plant roots; recycling essential plant nutrients; improve soil structure with positive impacts on groundwater and nutrient retaining capacity, and ultimately increase crop production $[9,10]$. In simple terms, soil health is crucial in providing a decent living ecosystem as a habitat for animals, plants and humans. Despite the essential roles, data on soil health is still rarely been utilized in Indonesia. Moreover, specific techniques or tools to assess or measure soil health still has not been developed the best of our knowledge. For soils that have not been assessed for soil health, a soil health assessment is needed as baseline data that describes the level of the health of the soil at the time. Furthermore, a soil health assessment is then carried out in a soil health monitoring and evaluation program to assess whether there has been a decline or improvement in the health of the soil. In this case, a soil health assessment is also needed for planning rehabilitation or remediation of soils that have experienced pollution or other forms of soil damage or degradation. For this reason, a stan-dard technique or method is needed that can be used extensively to assess the health of the soil in Indonesia periodically.

Despite the essential roles, data on soil health is still rarely been utilized in Indonesia. Moreover, specific techniques or tools to assess or measure soil health still has not been developed the best of our knowledge. For soils that have not been assessed for soil health, a soil health assessment is needed as baseline data that describes the level of the health of soil at the time. Furthermore, a soil health assessment is then carried out in a soil health monitoring and evaluation program to assess whether there has been a decline or improvement in the health of soil. In this case, soil health assessment is also needed for planning rehabilitation or remediation of soils that have experienced pollution or other forms of soil damage or degradation. For this reason, a standard technique or method is needed that can be used extensively to periodically assess the health of soil in Indonesia.

\section{LITERATURE REVIEW}

\section{A. Fundamental of Soil Health Assessment}

Soils are the interface between aquatic, atmospheric, and terrestrial ecosystems. A better understanding of the linkages between these systems and the role that soil plays those linkages has led to a new approach in assessing soil. Soil is a dynamic, living, natural body that plays many key roles in terrestrial ecosystems. Hence, the Chinese are saying that "The Soils the mother of all things $[11,12]$. The various functions of soil, as for land, described by Sombroek and Sims [10] are: 1) production function, 2) biotic environmental function, 3) climate-regulative function, 4) hydrologic function, 5) storage function, 6) waste and pollution control function, 7) living space function, 8) archive or heritage function, and 9) connective space function.

Soil health describes soil activities and soil dynamics based on soil functions. Given the variety and complexity of soil functions, it is not easy to determine standard soil health assessments or measurements that can be used extensively. Initially, around the 1930s, research on the assessment of soil conditions or quality still focused on the function of soil and the suitability of land for crop production, designing soil management and fertilization to achieve greater productivity and profits. The soil is the keystone of food security, water security, climate change mitigation, and biodiversity protection. Simply put, the soil is a living ecosystem deserving of equivalent analyses as animal or plant habits $[2,13]$. However, over time and the complexity of life, the focus on assessing land conditions has become wider. In addition to being associated with agricultural production, currently assessing soil conditions also leads to ecosystem assessment, environmental quality, and human health. This influences or determines in key parameters used in the assessment or measurement of soil conditions. However, it remains that the assessment of soil conditions, soil quality or soil health is carried out in various suitable ways through the measurement of the physical, chemical and biological characteristics of the soil.

Healthy soil does not contain elements of pollutants or contaminants that can disturb the health of humans, animals and plants and do not contribute to environmental pollution. It is characterized by being a habitat and ecosystem that is conducive to the proliferation of soil organisms (micro, meso and macro organisms). Healthy soil supports the lives of healthy and prosperous humans. In agriculture sector, healthy soils are associated with soils that have good soil quality. Healthy soils generally produce high agriculture productivity, both in terms of the quantity and quality 
of agriculture products. Healthy soils also have a high resilience and resistance to various disorders.

The tendency of consumers to maintain their health by more favoring agricultural food products that have better quality and nutritional content, tastes, and is not polluted by heavy metals and waste agrochemicals $[1,14,15,16,17]$ also should change the key parameters that are used for assessment to some extent. or measurement of soil health. There is a consideration that soil health also has the potential to help plants build their resistance and resilience for stress abiotic and biotic resulting in the selection of key parameters to assess the health of the soil to be more complex.

\section{B. Guidance for Selection of Key Parameters for Soil Health Assessment}

Depending on the purpose of the study or assessment, an assessment of soil health can use a different "set of indicators". The Minimum Data Set (MDS), which is a collection of selected key parameters for the assessment of agricultural production systems, can differ from agricultural systems that pay attention to the quality of their products $[5,18]$. Likewise, MDS for agricultural systems is certainly different from if we want to assess the health of the soil in residential areas or industries that are more focused on the health effects of land on environmental health. This is what causes the difficulty of establishing MDS which can be used extensively.

However, there are several key parameters that are often and widely used by various experts, researchers and practitioners in the field of soil science. For the physical soil properties including the effective soil depth, soil bulk density, soil drainage, soil permeability, soil infiltration, soil structure, soil texture, soil water holding capacity, soil erosion, soil resistance to erosion [19]. Some key parameters of soil chemicals include soil $\mathrm{pH}$, cation exchange capacity, nutrient availability, electrical conductivity, etc. As for soil biology, the key parameters that are often used are soil organic carbon, soil respiration, microbial biomass, metabolic quotient, and enzyme activities [20,21]. In Europe, measurable quantities of trace metals have been added to the environment for over 2000 years. Lately, waste and sewage sludge have become major potential sources of metal pollution of soils. At present, there are one set of critical levels of heavy metals in soil ( $\mathrm{Cd}, \mathrm{Cu}, \mathrm{Ni}, \mathrm{Pb}, \mathrm{Zn}, \mathrm{Hg}$ and $\mathrm{Cr}$ ) which all countries of the European Union (EU) [22].

\section{PROPOSED TECHNIQUE TO DEVELOP SCORING OF SOIL HEALTH INDEX (SHI) TO ASSESS SOIL HEALTH IN INDONESIA}

There is no tool that can be used to measure soil health directly. Soil health can be inferred using soil health indicators [23]. Soil health can be assessed or measured through several physical, chemical and biological properties of the soil selected as key parameters or modeling from a set of physical, chemical and biological data [24].

To select indicators used for assessment or measurement of soil health in Indonesia, the author uses some criteria proposed by some authors formerly. The criteria are the following i) correlate with ecosystem processes; ii) integration of physical, chemical and biological properties of soil; iii) has a fairly good sensitivity to soil changes due to human intervention [11]; iv) simple and easy to implement and easy to interpret [25]; and v) easy to use extensively [26].

The author selects a technique proposed to develop SHI that was developed by [27]. The technique is "score-based" and operates in two synergistic steps, namely: a) indicator selection and interpretation which entails the transformation of measured data into unit-less scores by involving the weighting coefficient of each selected indicator, and b) aggregation which combines individual scores into a single value. Combining soil properties into an overall single index such as SHI may make the assessment more meaningful and practical.

\section{PROPOSED SOIL KEY PARAMETERS AND WEIGHTING COEFFICIENT TO ASSESS SOIL HEALTH}

Selecting appropriate indicators is the foundation of soil health assessment. Considering that determining soil health index can require abundant data of land and soil properties, selection of soil parameters for assessing the SHI should consider the goal of the determination of soil health, data availability, the function of each soil parameter, and cost considerations.

The determination of SHI should involve soil parameters consisting of soil, chemical and biological properties that play the most important role in affecting soil health. Since each soil parameter can have a different level of role and function, so each soil parameter should have a different weighting coefficient (proportion) for the scoring of SHI. The selected parameters which are proposed in the scoring of the Soil Health Index for assessing soil health together with its function and weighting coefficient (proportion) are presented in Table 1. 
TABLE 1

SOIL PROPERTIES PROPOSED IN DEVELOPING FOR SOIL HEALTH INDEX AND ITS PROPORTION

\begin{tabular}{|c|c|c|c|c|}
\hline No & Soil Properties & Function & Proportion $^{a}$ & Remarks \\
\hline 1 & Effective soil depth & $\begin{array}{l}\text { Representing and volume of soil that can } \\
\text { provide total nutrients, water and gases } \\
\text { needed by plants and maximum capacity } \\
\text { or volume of water that can enter soil and } \\
\text { absorbed by soil matrix. }\end{array}$ & 0.07 & FO \\
\hline 2 & Soil Bulk Density & $\begin{array}{l}\text { Ability/easiness of plant root to enter and } \\
\text { penetrate the soil, representing soil aera- } \\
\text { tion and soil permeability }\end{array}$ & 0.07 & FO and/or LA \\
\hline 3 & Drainage & $\begin{array}{l}\text { Condition-related with inundating (flood) } \\
\text { that can impede human being activities } \\
\text { and soil aeration. }\end{array}$ & 0.06 & FO \\
\hline 4 & Soil erosion & $\begin{array}{l}\text { Loss of best, fertile and friable soil of the } \\
\text { top soil }\end{array}$ & 0.06 & FO and/or EP \\
\hline 5 & Infiltration rate & $\begin{array}{l}\text { Amount and velocity (rate) of water that } \\
\text { can enter the soil }\end{array}$ & 0.06 & FO \\
\hline 6 & Soil pH & $\begin{array}{l}\text { The indicator of soil reaction (acid or } \\
\text { base) and the availability of soil nutrients }\end{array}$ & 0.07 & FO and/or LA \\
\hline 7 & Electrical Conductivity & Amount of salts in the soil (salinity of soil) & 0.07 & FO and/or LA \\
\hline 8 & The content of hazardous elements & $\begin{array}{l}\text { Toxicity threat/hazard for a plant, animal, } \\
\text { and human being such as heavy metals or } \\
\text { other toxic elements ( } \mathrm{Cd}, \mathrm{Cu}, \mathrm{Ni}, \mathrm{Pb}, \mathrm{Zn}, \mathrm{Hg} \\
\text { and } \mathrm{Cr} \text { ) }\end{array}$ & 0.10 & LA \\
\hline 9 & Essential Macro Nutrients & $\begin{array}{l}\text { The available of Nitrogen, Phosphorus, } \\
\text { Potassium, Calcium (N, P, K, Ca) in the soil }\end{array}$ & 0.10 & LA \\
\hline 10 & Organic Carbon (Organic-C) & $\begin{array}{l}\text { The capacity to support living organism in } \\
\text { the soil }\end{array}$ & 0.10 & LA \\
\hline 11 & Microbial biomass $\mathrm{C}$ and $\mathrm{N}$ & $\begin{array}{l}\text { Estimate of a contribution of a soil-living } \\
\text { organism for soil health }\end{array}$ & 0.08 & LA \\
\hline 12 & Soil respiration & Estimate of abundant oil living organism & 0.08 & LA \\
\hline 13 & Ratio of Biomass $\mathrm{C}$ and Total organic $\mathrm{C}$ & Estimate of ecosystem stability ${ }^{\mathrm{b}}$ & 0.08 & LA \\
\hline
\end{tabular}

\section{A. Proposed Scoring of SHI and Classification of SHI Scoring of SHI}

The author proposes that the final score of SHI is calculated from the sum of a total score of each selected soil parameter. The total score of each soil parameter is founded from the multiplication of proportion (weighting coefficient) and score of each (soil) parameter (scale of 1 to 5). Thus, the total score of SHI, theoretically, varies from 0 to 5, let say 3.06, $4.89,2.45$, etc.

$$
\begin{gathered}
\operatorname{TSoP}_{i}=P_{i} x \text { SoP }_{i} \\
T S o S H I=\sum_{i}^{n} P_{i} x \text { SoP }_{i}
\end{gathered}
$$

Where: $T S o P_{i}=$ total score of soil parameter $i$ $P_{i}=$ Proportion (weighting coefficient) of soil parameter $i$ $S o P i=$ Score of soil parameter $i$ $n=$ Number of soil parameter TSoSHI = Sum of total score of SHI = score of SHI

\section{B. Classification of SHI Score}

The proposed categorization of the total score of SHI is presented in Table 2 as follows:

TABLE 2

CATEGORIZATION OF SHI

\begin{tabular}{ll}
\hline \hline & Number of SHI \\
\hline Very low & $\mathrm{SHI} \leq 1.00$ \\
Low & $1.00<\mathrm{SHI} \leq 2.00$ \\
Moderate & $2.00<\mathrm{SHI} \leq 3.00$ \\
High & $3.00<\mathrm{SHI} \leq 4.00$ \\
Very High & $4.0 \mathrm{SHI} \leq 5.00$ \\
\hline \hline
\end{tabular}

\section{DISCUSSION}

A challenge on applying soil health assessment in Indonesia lies in the minimum presence of data set regarding the soil properties. Thus, the assessment has only been limitedly performed and mostly only for agriculture purposes. Meanwhile, data on soil health is not available. Therefore, 
the steps and decisions taken by the author were to combine soil parameters to assess agricultural product quality and productivity with soil key parameters related to soil ecosystems and environmental health. By doing so, the author finally proposes 13 soil key parameters to assess or measure soil health.

Biological properties are receiving increasing attention as indicators of soil health as these properties are more sensitive to alterations in the soil environment than physical and chemical soil properties $[29,30]$. In some cases, indicators of soil health have been developed that only include the biological component based on the assumption that changes in chemical and physical properties will be related to the changes in the microbial community [31,32].

Soil health basically reflects the character and dynamics of the soil in fulfilling its functions. However, a variation on the function of soil causes difficulties in compiling a soil health assessment that can measure to which extent the soil can fulfill all of its dedicated functions. For example, if an assessment of soil health is focused more on the conditions of soil pollution and the environment, it would be less satisfying to assess the health of the soil associated with the level of agricultural or food production; and vice versa. If the assessment or measurement of soil health is designed to satisfy both, much soil parameters are needed to be re- lated to soil pollution and agricultural and food production. Meanwhile, in order to be able to be used extensively, the standard of soil health assessment must be quite easy and practical, affordable in terms of financing or not expensive and selected soil parameters can be analyzed by many land and water laboratories throughout Indonesia. Therefore, organic or nonorganic components or materials derived from the degradation of pesticides, herbicides, fungicide, and other agrochemicals are not selected as parameters that determine soil health because there are not many soil and water laboratories that can analyze them and will certainly require costs expensive. However, assessment of soil health that is more focused on environmental pollution can still be done by compiling an assessment or measurement of soil health for soil pollution and the environment.

\section{CONCLUSION}

This work proposes a technique of assessment or measurement of soil health in Indonesia. The proposed technique for the soil health assessment standard consists of 13 soil parameter components to calculate the soil health index. The resulting soil health index value is then categorized into 5 (five) classes. Soil health assessment by calculating the value of the soil health index is expected to be more practical, easy to implement and interpret, making it easier to use as a tool to monitor and evaluate soil health and its changes.

\section{REFERENCES}

[1] C. P. Bravo, A. Cordts, B. Schulze, and A. Spiller, “Assessing determinants of organic food consumption using data from the German National Nutrition Survey II," Food Quality and Preference, vol. 28, no. 1, pp. 60-70, 2013. doi: https://doi. org/10.1016/j.foodqual.2012.08.010

[2] A. McBratney, D. J. Field, and A. Koch, "The dimensions of soil security," Geoderma, vol. 213, pp. 203-213, 2014. doi: https://doi.org/10.1016/j.geoderma.2013.08.013

[3] M. A. M. Chusururi, D. Ravelia, W. S. Brahmanu, F. N. Ahmadi, L. Noerochiem, and B. A. Kurniawan, "Comparison of corrosion inhibitor performance based on green corrosion inhibitor of extract leaf tobacco and commercial imidazoline inhibitor in a sweet environment at carbon steel AISI 1045 in NaCl 3.5 percent solution," Journal of Applied and Physical Sciences, vol. 4, no. 1, pp. 14-25, 2018. doi: https://doi.org/10.20474/japs-4.1.3

[4] M. R. Carter, E. Gregorich, D. Anderson, J. Doran, H. Janzen, and F. Pierce, "Concepts of soil quality and their significance," Developments in Soil Science, vol. 25, no. 7, pp. 1-9, 1997. doi: https://doi.org/10.1016/S0166-2481(97)80028-1

[5] W. E. Larson and F. J. Pierce, "The dynamics of as a measure of sustainable management," in Defining Soil Quality for a Sustainable Environment SSSA, J. W. Doran, D. C. Coleman, D. F. Bezdicek, and B. A. Stewart, Eds. Madison, WI: Special Publication, 1994.

[6] J. W. Doran and M. R. Zeiss, "Soil health and sustainability: Managing the biotic component of soil quality," Applied Soil Ecology, vol. 15, no. 1, pp. 3-11, 2000. doi: https://doi.org/10.1016/S0929-1393(00)00067-6

[7] W. Wanja, L. Daniela, and R. Linda, "Importance of automobile interior for sustainability in the automotive industry: The case of volume manufacturers," Journal of Applied and Physical Sciences, vol. 4, no. 2, pp. 60-68, 2018. doi: https: //doi.org/10.20474/japs-4.2.3

[8] T.-H. Anderson, "Microbial eco-physiological indicators to asses soil quality," Agriculture, Ecosystems \& Environment, vol. 98, no. 1-3, pp. 285-293, 2003. doi: https://doi.org/10.1016/S0167-8809(03)00088-4 
[9] R. L. Haney, E. B. Haney, D. R. Smith, R. D. Harmel, and M. J. White, "The soil health tool: Theory and initial broad-scale application," Applied Sil Ecology, vol. 125, pp. 162-168, 2018. doi: https://doi.org/10.1016/j.apsoil.2017.07.035

[10] Food and Agriculture Organizatio, "An international technical workshop: Investing in sustainable crop intensification the case for improving soil health," 2008. [Online]. Available: https://bit.ly/20JcE71

[11] J. W. Doran and T. B. Parkin, "Defining and assessing soil quality," in Soil Science Society of America and American Society of Agronomy, J. W. Doran, D. C. Coleman, D. F. Bezdicek, and B. A. Stewart, Eds. Madison, WI: ASA Publisher, 1994.

[12] T. M. Mahmoud, "The effect of different types of soils on the germination rate of the watercress seeds (nasturtium officinal)," International Journal of Applied and Physical Sciences, vol. 2, no. 1, pp. 21-32, 2016. doi: https://doi.org/10. 20469/ijaps.2.50004-1

[13] H. Maizir, R. Suryanita, and H. Jingga, "Estimation of pile bearing capacity of single driven pile in sandy soil using finite element and artificial neural network methods," International Journal of Applied and Physical Sciences, vol. 2, no. 2, pp. 45-50, 2016. doi: https://doi.org/10.20469/ijaps.2.50003-2

[14] P. R. Williams and J. K. Hammitt, "Perceived risks of conventional and organic produce: Pesticides, pathogens, and natural toxins," Risk Analysis, vol. 21, no. 2, pp. 319-330, 2001. doi: https://doi.org/10.1111/0272-4332.212114

[15] E. K. Yiridoe, S. Bonti-Ankomah, and R. C. Martin, "Comparison of consumer perceptions and preference toward organic versus conventionally produced foods: A review and update of the literature," Renewable Agriculture and Food Systems, vol. 20, no. 4, pp. 193-205, 2005. doi: https://doi.org/10.1079/RAF2005113

[16] M. Siegrist, "Factors influencing public acceptance of innovative food technologies and products," Trends in Food Science \& Technology, vol. 19, no. 11, pp. 603-608, 2008. doi: https://doi.org/10.1016/j.tifs.2008.01.017

[17] G. Pino, A. M. Peluso, and G. Guido, "Determinants of regular and occasional consumers' intentions to buy organic food," Journal of Consumer Affairs, vol. 46, no. 1, pp. 157-169, 2012. doi: https://doi.org/10.1111/j.1745-6606.2012.01223.x

[18] W. Larson and F. Pierce, "Conservation and enhancement of soil quality," in International Workshop on Evaluation for Sustainable Land Management in the Developing World, Chiang Rai, Thailand, 1991.

[19] S. H. Schoenholtz, H. Van Miegroet, and J. Burger, "A review of chemical and physical properties as indicators of forest soil quality: Challenges and opportunities," Forest Ecology and Management, vol. 138, no. 1-3, pp. 335-356, 2000. doi: https://doi.org/10.1016/S0378-1127(00)00423-0

[20] F. Gil-Sotres, C. Trasar-Cepeda, M. Leirós, and S. Seoane, "Different approaches to evaluating soil quality using biochemical properties,"' Soil Biology and Biochemistry, vol. 37, no. 5, pp. 877-887, 2005. doi: https://doi.org/10.1016/j. soilbio.2004.10.003

[21] E. J. B. N. Cardoso, R. L. F. Vasconcellos, D. Bini, M. Y. H. Miyauchi, C. A. d. Santos, P. R. L. Alves, A. M. d. Paula, A. S. Nakatani, J. d. M. Pereira, and M. A. Nogueira, "Soil health: Looking for suitable indicators what should be considered to assess the effects of use and management on soil health?" Scientia Agricola, vol. 70, no. 4, pp. 274-289, 2013. doi: https://doi.org/10.1590/S0103-90162013000400009

[22] M. A. Arshad and S. Martin, "Identifying critical limits for soil quality indicators in agro-ecosystems," Agriculture, Ecosystems \& Environment, vol. 88, no. 2, pp. 153-160, 2002. doi: https://doi.org/10.1016/S0167-8809(01)00252-3

[23] S. M. J. Sione, M. G. Wilson, M. Lado, and A. P. González, "Evaluation of soil degradation produced by rice crop systems in a vertisol, using a soil quality index," Catena, vol. 150, pp. 79-86, 2017. doi: https://doi.org/10.1016/j.catena.2016. 11.011

[24] R. Lal, "Managing world soils for food security and environmental quality," Advances in Agrnonomy, vol. 74, no. 6, pp. 155-192, 2001. doi: https://doi.org/10.1016/S0065-2113(01)74033-3

[25] E. Viglizzo, F. Lértora, A. Pordomingo, J. Bernardos, Z. Roberto, and H. Del Valle, "Ecological lessons and applications from one century of low external-input farming in the pampas of Argentina," Agriculture, Ecosystems \& Environment, vol. 83, no. 1-2, pp. 65-81, 2001.

[26] E. Gregorich, M. Carter, D. Angers, C. Monreal, and B. Ellert, “Towards a minimum data set to assess soil organic matter quality in agricultural soils," Canadian Journal of Soil Science, vol. 74, no. 4, pp. 367-385, 1994. doi: https://doi.org/10. 4141/cjss94-051

[27] V. De Paul Obade and R. Lal, 'Towards a standard technique for soil quality assessment," Geoderma, vol. 265, pp. 96-102, 2016. doi: https://doi.org/10.1016/j.geoderma.2015.11.023

[28] S. Visser and D. Parkinson, "Soil biological criteria as indicators of soil quality: Soil microorganisms," American Journal 
of Alternative Agriculture, vol. 7, no. 1-2, pp. 33-37, 1992. doi: https://doi.org/10.1017/S0889189300004434

[29] M. D. L. P. Jimenez, A. D. L. Horra, L. Pruzzo, and M. R. Palma, "Soil quality: A new index based on microbiological and biochemical parameters," Biology and Fertility of Soils, vol. 35, no. 4, pp. 302-306, 2002. doi: https://doi.org/10.1007/ s00374-002-0450-z

[30] P. Nannipieri, J. Ascher, M. Ceccherini, L. Landi, G. Pietramellara, and G. Renella, "Microbial diversity and soil functions," European Journal of Soil Science, vol. 54, no. 4, pp. 655-670, 2003. doi: https://doi.org/10.1046/j.1351-0754.2003. 0556.x

[31] E. Puglisi, A. Del Re, M. Rao, and L. Gianfreda, "Development and validation of numerical indexes integrating enzyme activities of soils," Soil Biology and Biochemistry, vol. 38, no. 7, pp. 1673-1681, 2006. doi: https://doi.org/10.1016/j. soilbio.2005.11.021

[32] R. Romaniuk, L. Giuffré, A. Costantini, N. Bartoloni, and P. Nannipieri, “A comparison of indexing methods to evaluate quality of soils: The role of soil microbiological properties," Soil Research, vol. 49, no. 8, pp. 733-741, 2012. doi: https: //doi.org/10.1071/SR11147 